\title{
Ettliella tetraspora (Chlorophyta, Chlorophyceae): life cycle and taxonomy
}

\author{
František HindÁK \& Alica HindÁKovÁ
}

Institute of Botany, Slovak Academy of Sciences, Dúbravská cesta 9, SK-84523 Bratislava, Slovakia; e-mail: frantisek.hindak@savba.sk; alica.hindakova@savba.sk

\begin{abstract}
The morphology and mode of reproduction in Ettiella tetraspora HINDÁK 1988, a green coenobial alga described from the Czech Republic and Finland, were studied from the plankton of the water reservoir Förmitzspeicher in NE Bavaria, Germany. The morphology of cells and coenobia of the species in this population was in agreement with published data for the species, but its reproduction was not of the Oocystis - type as it has been declared in the relevant literature. The protoplast of mother cells does not divide simultaneously into 4 autospores as in many coccal green algae, but always in two autospores. The first division of the mother cell is perpendicular to the longitudinal axis of the cell and two walled daughter cells arise. Subsequently, the newly formed daughter cells divide again, but this time perpendicular to the new formed cell cross wall. Ultimately, in a new coenobium all four daughter cells are arranged in parallel. Daughter cells remain inside a slightly enlarged mother cell wall (well visible only near the cross wall) and are released by its gelatinisation. Such subsequent production of four autospores from the mother cell represents a special type of multiplication in the green coccal algae known also in some other species [e.g. Tetrastrum komarekii HINDÁK 1977, Willea irregularis (WILLE) SCHMidle 1900, Makinoella tosaensis OKADA 1949].
\end{abstract}

Key words: autospores subsequent division, coenobial green algae, taxonomy, Oocystaceae, Scenedesmaceae, Germany

\section{Introduction}

During a workshop devoted to the determination of planktic cyanophytes and chlorophytes of lakes and reservoirs organised by the Bavarian Regional Office for the Environment (Bayerisches Landesamt für Umwelt) in Wielenbach, Germany, in July 2010, samples from several local water bodies were analysed. In the phytoplankton sample collected from the water reservoir Förmitzspeicher a rare coccal green alga, Ettliella tetraspora, was observed.

The monotypic genus Ettliella HiNDÁK 1988 including E. tetraspora HINDÁK 1988 was described on the basis of two observations. ETTL (1965) was the first to find the alga in a fishpond near Svitavy in Moravia, the Czech Republic, but designated it as Tetrachlorella cf. alternans KORSHIKOV (?nov. var.) (cf. also KOMÁREK \& FotT 1983; HindÁK 1988). Later, HindÁK (1988) observed it in a lake near Jyväskylä, Central Finland. The morphology of cells and colonies and the formation of autospores were similar in material from both localities. Ettl was of the opinion that the mother cell wall expands during autosporulation and therefore he assigned the alga to the family Oocystaceae. When HINDÁK (1988) established this alga as a new genus and species, Ettliella tetraspora, he followed this classification, although the release of autospores and remnants of mother cell walls were not observed in detail. It was noticed, however, that the regular Tetradesmus - like clustering of cells of Ettliella is reminiscent of some representatives of the family Coelastraceae or Scenedesmaceae.

In one phytoplankton sample from Bavaria, coenobia of Ettliella tetraspora occurred quite abundantly, thereby offering an opportunity to study the process of autosporulation in all its stages. These observations led to the conclusion that the mother cell wall does not expand before the liberation of autospores as in the Oocystaceae. Probably EтTL (1965) did not depict expanded mother cell walls around daughter coenobia, but mucilaginous envelopes newly formed around autocoenobia.

\section{Material and Methods}

Plankton samples were collected from the water 
reservoir Förmitzspeicher (Förmitzsee) near Schwarzenbach a.d. Saale, NE Bavaria, Germany, $\mathrm{pH}$ 7.9, July 5, 2010, by Mrs C. Hauenschild, Hof, using a plankton net with $10 \mu \mathrm{m}$ mesh size (Fig. 1).

Cyanophytes and algae were determined according to KORSHIKOV (1953), HINDÁK (1977, 1980, 1984, 1988, 1990, 2008), KoMÁrEK \& FotT (1983), Krammer \& Lange-Bertalot (1986, 1988, 1991a, b), KomÁrek \& ANAgnostidis (1998, 2005), KomÁreK \& ZAPOMNĚLovÁ (2007), LENZENWEger (1999) and RAJANIEMI et al. (2005). Identifications were performed on living material. Light microscope observations were carried out with a Leitz Diaplan microscope, and photomicrographs were taken with a Wild Photoautomat MPS45. Preserved material in formaldehyde is stored at the Institute of Botany SAS, Bratislava. Attempts to cultivate this organism under laboratory conditions were unsuccessful.

\section{Results}

\section{Ettliella tetraspora HıNdÁK (Figs 2-9)}

Coenobia free floating, solitary, usually 4-8(16)celled, ovoid to spherical, $40-60 \mu \mathrm{m}$ in diameter, or cells solitary before reproduction, embedded by wide homogeneous hyaline mucilaginous envelopes. Cells in coenobia clustered into tetrads as in Tetradesmus G.M. SMiтH, i.e. positioned (but not joined) in parallel next to each other forming a square when viewed from above, with a central opening (Figs 2-4). Cells broadly ovoid or short cylindrical, before division slightly asymmetrical to kidney-shaped, 8-12(18) × 6-8(10) $\mu \mathrm{m}$, ends broadly oval. Cell walls thick, smooth, without incrustations or conspicuous polar thickenings. Chloroplasts single, bright green, parietal, transversely pot-shaped, with a large central starch-associated pyrenoid, and in cells in tetrads oriented toward the external side. Reproduction by autocoenobia with 4 autospores. Coenobia before autosporulation mostly disintegrating into solitary cells, losing their tetrahedrical arrangement of cells (Figs 5-8). When autospores are formed, colonies arise temporarily with tetrads of young cells, so that composite colonies exhibit cell tetrads of a similar clustering (Figs 7-9).

Although the product of autosporulation is one 4

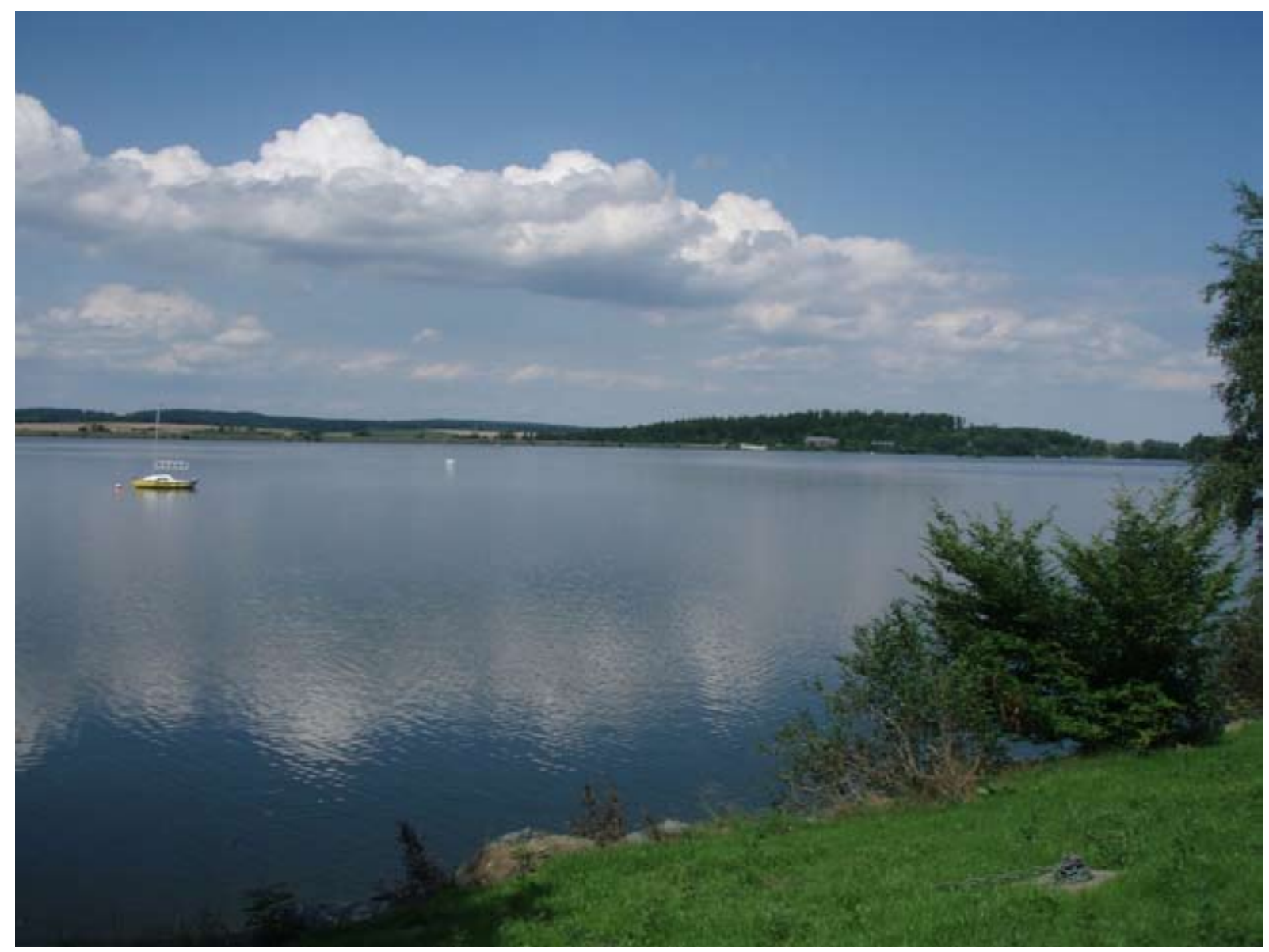

Fig. 1. Locality where Ettiella tetraspora was collected: the water reservoir Förmitzspeicher in NE Bavaria, Germany (photo C. Hauenschild, summer 2010). 
Table 1. List of cyanophytes and algae found in the phytoplankton of the water reservoir Förmitzspeicher, Germany.

\author{
Cyanophyceae \\ Aphanocapsa delicatissima W. et G.S. WEST \\ Aphanocapsa planctonica (G.M. SMITH) KOMÁREK et \\ ANAGNOSTIDIS \\ Aphanothece clathrata W. et G.S. WEST \\ Aphanothece nidulans Richter in WitTROcK et NORDSTEDT \\ Chroococcus limneticus LeMmERMANN \\ Chroococcus minutus (KÜTZING) NÄGELI \\ Eucapsis minor (SKUJA) ELENKIN \\ Merismopedia glauca (EHRENBERG) KÜTZING \\ Merismopedia minima $\mathrm{BECK}$ \\ Microcystis aeruginosa (KüTZING) KÜTZING \\ Microcystis flos-aquae (WITTROCK) KIRCHNER \\ Snowella litoralis (HÄYRÉN) KOMÁREK et HINDÁK \\ Synechococcus endophyticus (W. et G.S. WeSt) Joosten \\ Woronichinia naegeliana (UNGER) ELENKIN \\ Oscillatoria limosa Agardh ex Gomont \\ Pseudanabaena catenata LAUTERBORN \\ Pseudanabaena mucicola (NAUMANn et Huber-Pestalozzi) \\ SCHWABE \\ Anabaena mucosa KomÁrKová-Legnerová et Eloranta \\ Anabaena planctonica BRUNNTHALER
}

\section{Bacillariophyceae}

Aulacoseira ambigua (GRUNOw) SiMONSEN

Cyclotella balatonis PANTOCZEK

Discostella pseudostelligera (Hustedt) Houk et KLEE

Melosira varians C. AGARDH

Stephanodiscus medius HÅKansson

Achnanthes laevis OestruP

Achnanthes lanceolata ssp. frequentissima LANGE-BERTALOT

Achnanthes minutissima KüTZING

Achnanthes cf. petersenii HUSTEDT

Achnanthes cf. saccula J. R. CARTER

Caloneis silicula (EHRENBERG) CLEVE

Cymbella gracilis (EHRENBERG) KÜTZING

Cymbella silesiaca BLEISCH

Eunotia bilunaris (EHRENBERG) Mills

Eunotia praerupta var. bidens (EHRENBERG) GRUNOw

Fragilaria crotonensis KITTON

Fragilaria tenera (W. SMITH) LANGE-BERTALOT

Fragilaria ulna var. acus (KÜTZING) LANGE-BERTALOT

Frustulia vulgaris (Thwaites) De ToNI

Gomphonema angustatum (KÜTZING) RABENHORST

Gomphonema parvulum (KÜTZING) KÜTZING

Navicula capitata EHRENBERG

Navicula capitatoradiata H. GERMAIN

Navicula cryptocephala KüTZING

Navicula cryptotenella LANGE-BERTALOT

Navicula detenta HustedT

Navicula rhynchocephala KÜTZING

Nitzschia angustiforaminata LANGE-BERTALOT

Nitzschia fonticola GruNOw

Nitzschia hantzschiana RABENHORST

Nitzschia cf. liebetruthii RABENHORST

Nitzschia palea (KÜTZING) W. SMITH

Nitzschia valdestriata AleEm et Hustedt

Pinnularia divergens var. media KRAMMER

Tabellaria flocculosa (Rотн) KüTZING

\author{
Chlorophyceae \\ Carteria globosa KorshiKov ex PAscher \\ Chlamydomonas passiva SKUJA \\ Eudorina elegans EHRENBERG \\ Asterococcus limneticus G.M. SMITH \\ Ankistrodesmus falcatus (CORDA) RALFS \\ Ankistrodesmus spiralis (W.B. TURNER) LEMMERMANN \\ Botryococcus braunii KüTZING \\ Closteriopsis acicularis (G.M. SMITH) J.H. BELCHER et \\ SWALE \\ Coelastrum pseudomicroporum KORSHIKOV \\ Coenochloris polycoccus (KORSHIKOv) HINDÁK \\ Coenocystis planctonica KORSHIKOV \\ Crucigeniella apiculata (LEMMERMANN) KOMÁREK \\ Desmodesmus abundans (Kirchner) E.H. Hegewald \\ Desmodesmus armatus (СHоDAт) E.H. Hegewald \\ Desmodesmus brasiliensis (BoHLin) E.H. Hegewald \\ Desmodesmus communis (E.H. Hegewald) E.H. Hegewald \\ Desmodesmus dispar (BRÉBISSON) E.H. HegEWALD \\ Desmodesmus maximus (W. et G.S. West) E.H. Hegewald \\ Desmodesmus serratus (CORDA) An, FrIEDL et E.H. \\ Hegewald \\ Desmodesmus subspicatus (Chodat) E.H. Hegewald et A. \\ SCHMIDT \\ Dictyosphaerium tetrachotomum PRINTZ \\ Ettliella tetraspora HiNDÁK \\ Komarekia appendiculata (CHODAT) FOTT \\ Monoraphidium griffithii (BERKELEY) KOMÁRKOVÁ- \\ LEGNEROVÁ \\ Oocystella borgei (J. SNOw) HINDÁK \\ Oocystella lacustris (CHODAT) HINDÁK \\ Oocystella marssonii (LEMMERMANN) HINDÁK \\ Pediastrum biradiatum MeYen \\ Pediastrum boryanum (TuRPIN) MENEGHINI \\ Pediastrum duplex Meyen \\ Pediastrum tetras (EHRENBERG) RALFS \\ Pseudodictyosphaerium minusculum HINDÁk \\ Pseudodidymocystis inconspicua (KoRshiKov) Hindák \\ Pseudokirchneriella contorta (SCHMIDLE) HINDÁK \\ Pseudokirchneriella irregularis (G.M. SMITH) HINDÁK \\ Scenedesmus acuminatus (LAGERHEIM) CHODAT \\ Scenedesmus arcuatus (LemmermanN) LemMermanN \\ Scenedesmus obliquus (TurPIN) KütZING \\ Scenedesmus obtusus MeYEN \\ Selenastrum bibraianum REINSCH \\ Tetraedron caudatum (CORDA) HANSGIRG \\ Willea irregularis SCHMIDLE
}

\section{Zygnematophyceae}

Cosmarium circulare REINSCH

Cosmarium hornavanense GUTWINSKI

Staurastrum cuspidatum BRÉBISSON

Staurastrum mucronatum RALFs ex RALFS

Staurastrum planctonicum TeILING

Staurastrum punctulatum BRÉBISSON

Euglenophyceae

Trachelomonas planctonica SWIRENKO 

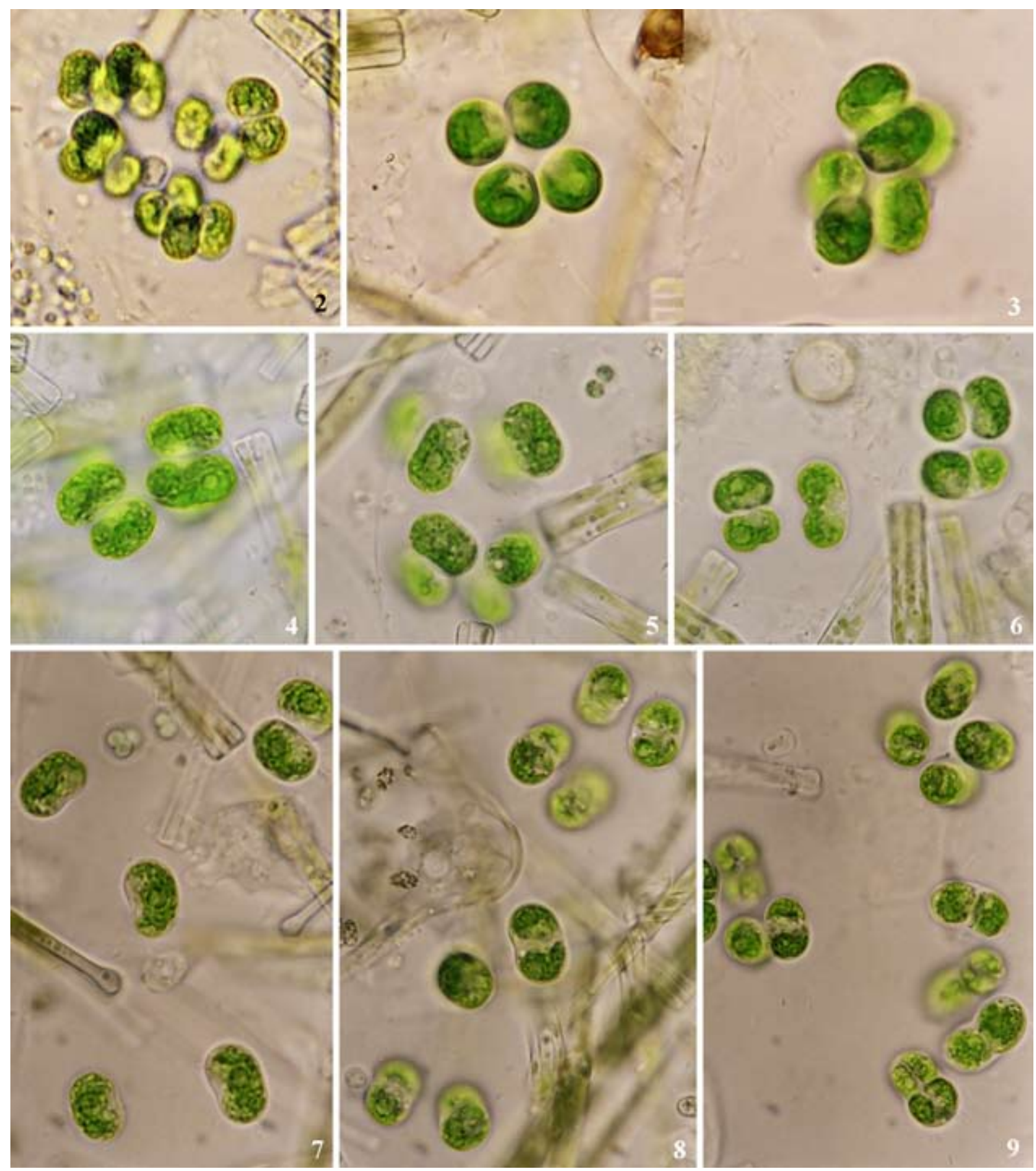

Figs 2-9. Coenobia of Ettiella tetraspora from natural material: (2) coenobia at low magnification; (3) coenobia from the top and lateral view; (4) coenobia from the lateral view; $(5,6)$ disintegration of coenobia; $(7-9)$ division of cells into two daughter cells.

-celled coenobium, the protoplast of mother cells and subsequently daughter cells divides always into two steps. First division of the mother cell is perpendicular to the longitudinal axis of the cell and two walled daughter cells arise (Figs 7,8). Subsequently, new daughter cells divide again, but perpendicular to the new cell wall. Daughter cells remain in a slightly enlarged mother cell wall near the cross wall and are released by its gelatinisation
(Fig. 9). Finally, in a new coenobium all four daughter cells are arranged in parallel (Fig. 3).

Our material does not differ significantly from published descriptions of the species except for the size of cells and coenobia, which are larger than mentioned by ETTL (1965) or HINDÁK (1988). In contrast to a previous observation of the alga from Finland, 2-celled coenobia were not found in the German material. 


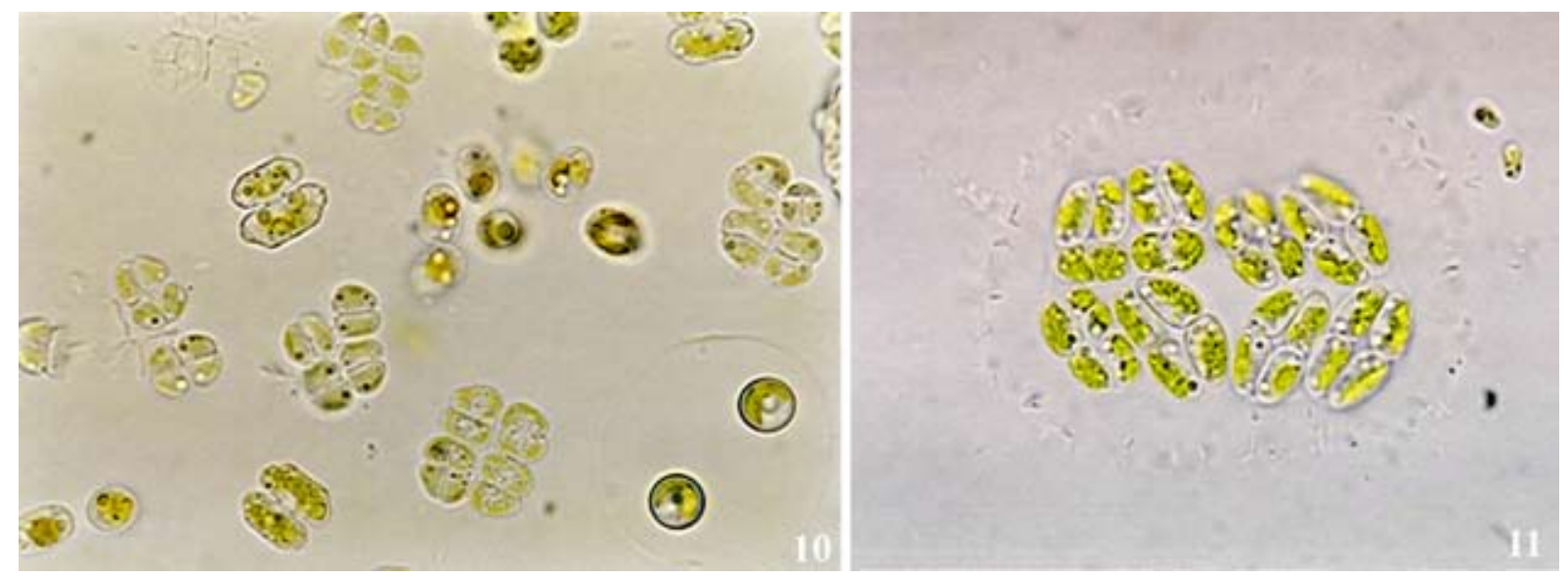

Fig. 10. Tetrastrum komarekii, formation of 4-celled coenobia. Fig. 11. Willea irregularis, formation of 4-celled coenobia.

Coenobia of E. tetraspora occurred quite abundantly among other members of the phytoplankton assemblage of the water reservoir Förmitzspeicher. The cyanophycean water bloom consisted mainly of colonies of Woronichinia naegeliana (UNGER) ELENKIN with endogloeic Synechococcus endophyticus (W. et G.S. WeST) Joosten (HindÁk 2008), Microcystis aeruginosa (KÜTZING) KütZING and filaments of Anabaena mucosa KomÁrková-Legnerová et Eloranta (KomÁreK \& ANAGNOSTIDIS 1998; RAJANIEMI et al. 2005; KomÁreK \& ZAPOMNĚLOVÁ 2007). The diatoms Fragilaria crotonensis KITTON and F. tenera (W. Smith) Lange-Bertalot were amongst the dominant phytoplankton species. In the following list of found taxa we used the classification system by HINDÁK \& HINDÁKOvÁ (1998), which has been adopted for the algal flora databank at our institute.

The occurrence of Ettliella tetraspora in the plankton of stagnant mesotrophic water basins seems to be typical for the species. In the Czech Republic it was found in a fishpond near Svitavy (ETTL 1965), and we have reported this species from the lake Patalakti near Jyväskylä in Finland (HindÁk 1988). However, Stoyneva (2000) recorded E. tetraspora from the Alepou swamp, a wetland on Southern Black Sea coast, Bulgaria, but did not provide a description or figure.

\section{Discussion}

The taxonomic position of Ettliella tetraspora [as Tetrachlorella cf.alternans KORSHIKOv(?nov.var.)] in the Chlorococcales was originally determined by Ettl, who placed it in the family Oocystaceae, but KomÁré \& FotT (1983) classified the genus Tetrachlorella KonshiKov (together with $T$. cf. alternans nov. var. (?) sensu EтTL) in the family Scenedesmaceae. However, the latter authors noted that the parallel arrangement of cells in a coenobium precludes the classification of this alga in the genus Tetrachlorella KorshiKov 1953 which is characterised by flat coenobia, and suggested that it might be considered as a new species and genus. HINDÁK (1988) on the basis of material from a Finnish lake accepted this opinion and established Ettliella tetraspora as a new member of the family Oocystaceae, although the release of autospores and remnants of mother cell walls were not observed in detail.

Successive cell division of mother cells into 4 autospores is character that is found also in other coccal green algae, e.g. Tetrastrum komarekii НıNDÁK (Fig. 10), Willea irregularis (Wille) Schmidle (Fig. 11) (Korshikov 1953; HindÁk 1977, 1980, 1988; KomÁrek \& FotT 1983) and Makinoella tosaensis Okada (HINDÁK \& HINDÁKOvÁ 2010). Although the final product of autosporulation in these genera is a 4-celled coenobium, mother cells and subsequently daughter cells do not divide simultaneously into 4 autospores, but always into two parts/autospores, not in four or more parts/autospores like in many coccal green algae. Similarly, the chloroplast divides before the protoplast division only in two portions, not in four.

The placement of the genus Ettliella into a higher taxonomic unit is not yet clear. The mode of reproduction, together with the feature that mother cell wall does not significantly enlarge before the release of autospores, precludes the placement of Ettliella in the family Oocystaceae. The method of 
coenobium formation is suggestive of a taxonomic affinity with the family Scenedesmaceae sensu KOMÁREK \& FotT (1983), particularly the subfamily Crucigeniodeae and the genus Willea SchmideE. However, there are some arguments to let Ettliella tetraspora placed in the Oocystaceae. Members of the other genera with similar propagation pattern as Ettliella like Makinoella and Tetrachlorella are already molecular-phylogenetic characterized and confirmed members of the Oocystaceae (PAžoutová et al. 2010). It was also shown that several similar in mode of reproduction crucigenoid green algae such as Crucigeniella belong to Oocystaceae (KRIENITZ et al. 2003). A final taxonomical decision on Ettliella must await the results of an ultrastructural investigation of the cell wall and molecular taxonomic studies.

\section{Acknowledgements}

The authors are obliged to Dr. J. Schaumburg and Dr. R. Klee for their kind invitation to take part at the workshop in Wielenbach, Mrs C. Hauenschild, Hof, for providing material from the water reservoir Förmitzspeicher, and Dr. H. Sluiman, Edinburgh, for valuable comments and correcting the English. This study is a part of APVV 0566-07 and VEGA projects 2/0130/10 and 2/0113/11 supported by the Slovak Academy of Sciences.

\section{References}

Etrl, H. (1965): Die Algenflora des Schönhengstes und seiner Umgebung. II. - Nova Hedwigia 10: $121-159$, Tab. 43.

HindÁk, F. (1977): Studies on the chlorococcal algae (Chlorophycea). I. - Biol. Práce, Bratislava 23: 1-192.

HindÁK, F. (1980): Studies on the chlorococcal algae (Chlorophyceae). II. - Biol. Práce, Bratislava 26: 1-196.

HindÁk, F. (1984): Studies on the chlorococcal algae (Chlorophyceae). III. - Biol. Práce, Bratislava 30: $1-310$.

Hindák, F. (1988): Studies on the chlorococcal algae (Chlorophyceae). IV. - Biol. Práce, Bratislava 34: 1-264.

Hindák, F. (1990): Studies on the chlorococcal algae (Chlorophyceae). V. - Biol. Práce, Bratislava 36: $1-228$.

HindÁK, F. (2008): Colour Atlas of Cyanophytes. - 256 pp., Veda, Bratislava.

HindÁK, F. \& HindÁKovÁ, A. (1998): Zoznam siníc a rias Slovenska [Checklist of cyanophytes/ cyanobacteria and algae of Slovakia]. - . In: MARHOLd, K. \& HindÁK, F. (eds): Zoznam nižších a vyšších rastlín Slovenska [Checklist of non-vascular and vascular plants of Slovakia]. pp. 12-100, Veda, Bratislava.

Hindák, F. \& Hindáková, A. (2010): First record of Makinoella tasaensis Okada (Chlorophyceae, Oocystaceae) outside East Asia. - Fottea 10: 141-144.

KomÁreK, J. \& AnAgnostidis, K. (1998): Cyanoprokaryota 1. Teil Chroococcales. In: Ettl, H.; Gärtner, G.; Heynig, G. \& Mollenhauer, D. (eds): Süsswasserflora von Mitteleuropa 19/1. - 548 pp., Gustav Fischer, Jena -Stuttgart - Lübeck - Ulm.

Komárek, J. \& Anagnostidis, K. (2005): Cyanoprokaryota 2. Teil Oscillatoriales. In: Büdel, B.; Gärtner, G.; Krienitz, L. \& SCHLAGER, M. (eds): Süsswasserflora von Mitteleuropa 19/2. - 759 pp., Gustav Fischer, Elsevier, München.

KomÁrek, J. \& Fotт, B. (1983): Das Phytoplankton des Süßwassers. - In: Huber-Pestalozzi, G.; Elster, H.-J. \& Ohle, W. (eds): Die Binnengewässer, Band XVI. - 1044 pp., E. Schweitzerbarts Verlagsbuchhandluhg, Stuttgart.

KomÁreK, J. \& ZapomnělovÁ, E. (2007): Planktic morphospecies of the cyanobacterial genus Anabaena $=$ subg. Dolichospermum -1 . part coiled types. - Fottea 7: 1-31.

Korshikov, O.A. (1953): Pidklas Protokokovi (Protococcinae). - In: Roll, J. V.; OKSner, A.M. \& TonacevskiI, O.V. (eds): Vizn. Prisnovod. Vodorostei Ukrainskoi RSR 5. - 436 pp., Academy of Science Ukrainskoi RSR, Kyiv.

Krammer, K. \& Lange-Bertalot, H. 1986: Bacillariophyceae, 1. Teil: Naviculaceae. - In: Ettl, H.; Gerloff , J.; Heynig, H. \& Mollenhauer, D. (eds): Süßwasserflora von Mitteleuropa 2/1. - 876 pp., Gustav Fischer Verlag, Stuttgart - Jena.

Krammer, K. \& Lange-Bertalot, H. 1988: Bacillariophyceae, 2. Teil: Bacillariaceae, Epithemiaceae, Surirellaceae. - In: Eтtr, H.; Gerloff , J.; Heynig, H. \& Mollenhauer, D. (eds): Süßwasserflora von Mitteleuropa 2/2. - 596 pp., Gustav Fischer Verlag, Stuttgart Jena.

Krammer, K. \& Lange-Bertalot, H. 1991a: Bacillariophyceae, 3. Teil: Centrales, Fragilariaceae, Eunotiaceae. - In: EtTL, H.; Gerloff , J.; Heynig, H. \& Mollenhauer, D. (eds): Süßwasserflora von Mitteleuropa 2/3. - 576 pp., Gustav Fischer Verlag, Stuttgart Jena.

Krammer, K. \& Lange-Bertalot, H. 1991b: Bacillariophyceae, 4. Teil: Achnanthaceae, Kritische Ergänzungen zu Navicula (Lineolatae) und Gomphonema. - In: EтtL, H.; Gerloff , J.; Heynig, H. \& Mollenhauer, D. 
(eds): Süßwasserflora von Mitteleuropa 2/4. - 437 pp., Gustav Fischer Verlag, Stuttgart Jena.

Krienitz, L.; Hegewald, E.; Hepperle, D. \& Wolf, M. (2003): The systematics of coccoid green algae: 18S rRNA gene sequence data versus morphology. - Biologia 58: 437-446.

LENZENWEGER, R. (1999): Desmidiaceenflora von Österreich, Teil 3. - Bibliotheca Phycologica 104: $1-218$.

Pažoutová, M.; Škaloup, P. \& Nemjová, K. (2010): Phylogenetic position of Ooplanctella planoconvexa, gen. et comb. nova and Echinocoleum elegans (Oocystaceae, Trebouxiophyceae, Chlorophyta). - Fottea 10: 75-82.

Rajaniemi, P.; Hrouzek, P.; Kaštovská, K.; Wiliame, R.; Rantala, A.; Hoffmann, L.; KomáreK, J. \& Sivonen, K. (2005): Phylogenetic and morphological evaluation of the genera Anabaena, Aphanizomenon, Trichormus and Nostoc (Nostocales, Cyanobacteria). - Int. J. Syst. Evol. Morphology 55: $11-26$.

Stoyneva, M. (2000): Planktic algae of Bulgarian coastal wetlands. - Hydrobiologia 438: 25-41.

(C) Czech Phycological Society (2012)

Received February 4, 2011

Accepted May 2, 2011 